\title{
Traditional Aesthetic Exploration in Development of the Indonesian Contemporary Art
}

\author{
I Wayan Suardana ${ }^{1, *}$ \\ ${ }^{1}$ Yogyakarta State University, Yogyakarta, Indonesia \\ *Corresponding author.Email: Wayan_suardana@uny.ac.id
}

\begin{abstract}
Exploration is investigating or searching the traditional arts that exist in Indonesia. We know that Indonesia is rich country with traditional fine arts consisting of artifacts that can be seen visually, and are a legacy of ancestors that still remains sustainable in certain areas. Indonesian traditional fine art has distinctive features and has potential to be appointed as the future art, because it contains many religious values with distinctive and high quality artistic. Indonesian traditional fine art needs to be studied further, and adjusted according to the needs and support of the times. The aesthetic existence of traditional art is considered as a source of contemporary aesthetics. Traditional aesthetic has form or symbols that appear differently, however, the spirit, soul, or essence is still oriented to mystical, magical, cosmic, and religious culture. The presence of contemporary art with a traditional aesthetic background that represents the past art reflects activities that are based on the appreciation of life in universe, both for physical and non-physical needs. The previous art works were created based on a good awareness of depth function, aesthetics and symbolism which were mixed in a harmonious blend.
\end{abstract}

Keywords: Traditional Aesthetics Exploration, Contemporary Aesthetic

\section{INTRODUCTION}

\subsection{Background}

The Indonesian people are very rich with a variety of local / regional / traditional cultural arts, which are very strong wealth for the nation. Reality shows that Indonesia is rich in arts and culture, from each region from Sabang to Merauke, there are hundreds or maybe even thousands of arts, cultures, customs, habits that are indeed native to Indonesia. But maybe there are still many who do not understand, what types of arts, culture, customary, languages and customs are included as native to Indonesia. The diversity of Indonesian culture is almost virtually unlimited. It is said to be almost unlimited because research on art, culture, language and others is still very minimal. And very few are willing and motivated to do activities that can be said (maybe) not prestigious. It is precisely foreigners who are very interested and wants to study various matters related to the richness of Indonesian arts and culture.

The existence of Indonesian art and culture has a clear cultural identity that has a very plural identity and cultural character, by referring to the existing cultural diversity, it proves that our society has exceptional quality of cultural production. The function of the magical relics of prehistoric art displays manifestations in sculpture, painting, knitting and decoration which are rich in imagery and symbolic content. A symbol of the continuity of cosmological art traditions as they appear in a variety of ornaments and patra ornament. The tradition of the sacred art is still preserved in the plurality of ethnic culture with a variety of styles of expression. From the continuity of the Indonesian fine arts tradition form various diversitie, styles and types of new expression ini Hindu Era, Yudoseputro [2]. This country needs people who want to care about the past, present and future. Departing from the development which increasingly rapid and complex, not only developments in the fields of knowledge, science and technology, but also the increasingly widespread developments involving new values in the contemporary aesthetic world of culture. As we know, since individual freedom has gained a respected place in the expression of aesthetic ideas, it has also influenced the growth of our art and culture, including the field of fine arts.

Indonesia is very rich in art and culture, each region has characteristics that need not be doubted. Indonesian traditional art which has distinctive characteristics and has the potential to be promoted as the art of the future, besides containing many religious values, it also has distinctive artistic and high quality. Departing from the development which increasingly rapid and complex, not only developments in the fields of knowledge, science and technology, but also the increasingly widespread developments involving new values in the contemporary aesthetic world of culture. As we know, since individual freedom has gained a respected place in the expression of aesthetic ideas, it has also influenced the growth of our art and culture, including the field of fine arts. Bahasa rupa tidak universal karena terikat oleh ruang dan waktu (Primadi, 2000: 2 ). This opinion is very appropriate because each region has a different visual language. That is very reasonable because the environment, situations and conditions are different too, so it is possible that each region and at any given time has its own kind of visual language. It is something that cannot be denied and 
develops dynamically. A new life in our art has been born with old breath and values. In the fast pace of the development of our art, then new art that has been born individually, but has universal value, can make our beautiful art anesthetized with new pleasures, and we are reminded of old arts of ancestral heritage such as puppets, temples, and artifacts which are a small part of traditional culture that is said to have adhi luhung values. Apakah hendak kita perbuat dengannya? is the start of a tickling thought to be tried and traced, as a sense of responsibility of the testator to its continuity? What about the existence of contemporary art that has led to renewal and change oriented to patterns that lead the mainstream West?

Of course it is realized in the change and development of the aesthetic world, an artist cannot stop at a short point, he certainly will search and get, but obviously he will not be satisfied because a new problem has arisen to work into the latest work, and the latest will be followed by the newest invention as well so that it is an endless cycle, continued to connect to the last level brought to death or oppositely becomes saturated not to looking anymore because it never succeeded absolutely. Change is a necessity, the process of culture is always changing, creativity arises because new ideas are different from before, how a culture that is a new discovery changes the pattern of change of thought-behavior is a culture that must change all God's creations.

The existence of such awareness enables the search for new values, and new ones are always sought, carried out and applied at the same time as a sign of the possibility of a search for new values, and new ones are always sought, carried out and applied as well as a sign of the possibility of us turning back from old values (tradition) which was captured as a reference or source of inspiration to create new arts, specifically in fine arts, its life has been seen since prehistoric times. The development of fine arts was further influenced by a number of factors including customs, religion and natural conditions of the region, so that contemporary art was born which had its own characteristic and was different from art found in other countries. Today's visual art or contemporary art, in time review can contain a variety of trends that are still alive and continue to fight for its existence. That can include decorative painting, natural scenery, abstract, or in.form of forms new media art However, contemporary art can be viewed as a tendency for art forms to express new visual concepts and forms. Thus contemporary art is considered as art with a new aesthetic paradigm. Responding to the phenomena that are needed to love the traditional art which later as a foothold and source of inspiration in creating contemporary art [1].

\subsection{Indonesian Contemporary Fine Art Extensions}

Contemporary art is defined as current art, involving the style of art that questions the concepts of art in the past, namely modern art. So, if modern art is motivated by a modern paradigm, in time review can contain a variety of trends that are still alive and still fight for their existence. This can include decorative paintings, natural scenes, abstracts, or to new forms of media art. However, contemporary art can be viewed as a tendency for art forms to express new visual concepts and forms. Dengan demikian seni rupa kontemporer dianggap sebagai seni dengan paradigma estetik baru [1].

In Indonesia, contemporary art began in the 1980s to coincide with Indonesian modern art, which was entering its heyday in that year. Indonesian contemporary art is a culmination of global (ITB), national (ASRI), local (ITB and ASRI) issues, added to the Jakarta stronghold (IKJ), a mixture of these issues, especially global. The issue of nationalism, National identity, began with the pioneers of modern art. The history of Indonesian modern art which is still so short, which is around 60 years, around the founding of the academies of fine arts, has reached international association, so that global visual language is used as an orientation. But they are also aware of their local uniqueness, so that the art of local art becomes a capital also in the association of international artists [5]. Its existence has begun from the development of modern Indonesian art with the milestone of Raden Saleh, so all updates are always related to patterns that exist in the Western mainstream, and subsequently by the accelerating process of globalization. But other than that, there is always a movement that is diametrical than just following the symptoms that occur in the West. The process of finding an identity that emerges with the sentiment of nationalism always includes local contents and traditions [1]. Indonesian contemporary art artists who still use traditional spirits include; Nyoman Nuarta is known for its metal sculptures, taking many narratives of Balinese myths, tribal legends, national figures, and symbols. Edi Sunaryo highly appreciates the heritage of Indonesian ethnic traditions, Agus kamal with his works that give an impression of antiquity, similar to erosion-prone temple statues, Jim Supangkat with his Kendedes statue wearing jeans that are exposed to his pubic parts, Heri Dono painting, installation, and performing arts with character puppets made of caricaturist-surrealistic. And there are many more young painters who still wrestle contemporary art with traditional spirit.

From the description above it can be drawn a straight line that the presence of contemporary art with the traditional spirit of the archipelago which is the art of the past, this reflects the creation activities that are based on the appreciation of life in the universe, both to meet physical and non-physical needs. Artworks in the past were based on awareness, both concerning the depth of function, aesthetics and symbolism, mixed in a harmonious blend. Understanding the physical aspect gave birth to functional works that are as stable as the arts that are applied, while the understanding of physical aspects presents a large monumental work of art laden with symbolic meaning. The existence of cultural transformation and acculturation without sacrificing the existence of each generation, but instead it blends into a relative ingredient thanks to the ability to extract and crochet to link various influences that are alternating but beneficial for the development of the nation's homeland. In the course of history, it turns out that the creation activity has succeeded in giving birth to varied fine arts, both circulating in the environment of large traditions and in small traditions, which are all reflected the religious and religious ethos which are the main drivers for the presence of past works in the form of artifacts whose sustainability is still questioned 
in the era of modern human life today. This is so because people's attention today seems to be centered on the corners of the economy as well as being the measure of every business that is called success. As a result, the crisis of idealization and conceptual crisis arose, the old began to be abandoned while the new has not been fully discovered. Art creation today there is a tendency that is done, imitating, to meet the existing gaps and at most in the form of innovation or transfer of functions in various interests and applications. This is done in order to meet physical needs that are built on economic considerations and market tastes.

In the current era of development, the economic aspect is indeed an issue that appears "dominant" to the surface, and is clearly a strong motivation in artistic creativity activities because it promises worldly satisfaction. This can be calculated will take place in a period that is still prolonged, thereby encouraging the use of traditional works of the past as a trade commodity. For this reason, the existence of relics of the past in the form of artifacts has a common thread with the results / works of today's art or contemporary art. The artists try to present new forms with traditional art as a source of inspiration for his work.

\section{CONCLUSION}

Indonesian contemporary art, with a spirit of exploring the traditional art of the archipelago is very thick with a pluralistic local art and culture, cultural diversity is a potential for the development of arts that are unique and at the same time implies the uniqueness of each archipelago culture in each region. The richness of the local culture has not been maximally explored, even though it has a prospect that upholds eastern culture has its own characteristics that imply cultural values, physical environment

Indonesian contemporary art is a culmination of global (ITB), national (ASRI), local (ITB and ASRI) issues, added to the Jakarta stronghold (IKJ), a mixture of these issues, especially global. The issue of nationalism, national identity, begins with the pioneers of modern art. Then we need our awareness to instill a sense of shared ownership so that it can continue. Indonesian artists with contemporary works that are closely related to tradition and their view of pluralism globally, Indonesian art has greater opportunities to speak at various international forums. Its adaptability to change can be a medium for asserting group identity. It will provide space for the development of traditional arts.

Contemporary art with traditional spirit can be a means of appreciation that is sensitive to cultural differences, society, and the potential of diverse local traditions.

\section{REFERENCES}

[1] Burhan, M. Agus, and Soedarso Sp. Jaringan makna tradisi hingga kontemporer: kenangan purna bakti untuk Prof. Soedarso Sp., MA. A Network of Traditional to Contemporary: Retirement Memories for Prof. Soedarso Sp., MA.] BP ISI Yogyakarta, 2006.
[2] Yudoseputro, Wiyoso. Jejak-jejak tradisi bahasa rupa Indonesia lama [Traces of the old Indonesian language tradition]. Yayasan Seni Visual Indonesia, 2008.

[3] Sumarjo, Yakob. Asal usul seni rupa modern Indonesia. Kelir, 2009

[4] Tabrani, Primadi, Bahasa Rupa Gambar. Makalah Program Pelatihan Desain Grafis Bagi Desainer Peruri, Kerjasama Jurusan Desain FSRD-ITB Peruri.2000 